Gambaran Keterampilan Sosial....(Solihatun dan Maria Oktasari)

\title{
GAMBARAN KETERAMPILAN SOSIAL SISWA TERISOLIR SERTA IMPLIKASINYA DALAM PELAYANAN BIMBINGAN DAN KONSELING
}

\author{
Oleh: Solihatun ${ }^{1}$, Maria Oktasari ${ }^{2}$ \\ (Dosen Universitas Indraprasta PGRI Jakarta) \\ Email :solihatun@unindra.ac.id ${ }^{1}$ \\ Email:maria.oktasari@unindra.ac.id ${ }^{2}$
}

\begin{abstract}
Abstrak
Penelitian ini bertujuan untuk mengetahui gambaran keterampilan sosial bagi siswa terisolir. Penelitian ini menggunakan metode deskriptif dengan pendekatan kuantitatif. Populasi yang digunakan dalam penelitian ini sebanyak 3 kelas paralel yaitu kelas X, XI dan kelas XII yang berjumlah 672 siswa, dan untuk menentukan sampel atau kelas yang menjadi subjek penelitian digunakan teknik purposive sampling yaitu sampel diambil dengan maksud atau tujuan tertentu. Adapun sampel yang dipilih adalah kelas XI dengan jumlah 204 siswa. Dengan maksud bahwa kelas XI merupakan kelas di mana siswanya masih butuh beradaptasi dan memungkinkan masih terdapat siswa yang terisolir. Selanjutnya, untuk mengetahui siswa terisolir dari sampel di atas, maka digunakan alat sosiometri. Jika dilihat dari hasil sosiometri dapat terlihat bahwa siswa terisolir terdapat 15 orang, 2 orang siswa laki-laki dan 13 orang siswa perempuan. Instrumen keterampilan sosial yang digunakan adalah skala model Likert. Hasil penelitian menunjukkan bahwa keterampilan sosial siswa terisolir di SMKN 20 Cilandak Jakarta Selatan terlihat adanya 1 (6,7\%) siswa terisolir memiliki keterampilan sosial yang sangat rendah sedangkan untuk kategori rendah terdapat 5 (33,3\%) siswa terisolir. Kategori sedang 4 (26,7\%) siswa, kategori tinggi 3 (20\%) serta kategori sangat tinggi 2 (13,3\%). Implikasi hasil penelitian tersebut dapat dijadikan sebagai analisis kebutuhan siswa untuk pembuatan program BK dalam meningkatkan keterampilan sosial siswa terisolir.
\end{abstract}

Kata Kunci: Keterampilan Sosial, Siswa Terisolir

\section{DESCRIPTION OF SOCIAL STUDENTS 'SOCIAL SKILLS AND ITS IMPLICATIONS OF SERVICE SERVICES AND CONSELING SERVICES}

\begin{abstract}
This research aimed to know the description of the social skills for isolated students. This research method using a quantitative approach to deskriptif. The population used in this study as many as three parallel classes, namely the classes $X, X I$ and XII class of 672 students, and to determine the sample or the class became the subject of purposive sampling technique used research i.e. samples taken with the intent or purpose. As for the sample selected was a class XI with a total of 204 students. With the intention that the class XI is a class where his students still need to adapt and allow the students there are still isolated. Next, to
\end{abstract}


find out which students isolated from the samples above, then use the tool sosiometri. If seen from the results of sosiometri can be seen that isolated students there were 15 people, 2 person male students and female students 13 people. The instrument used is the social skill scale Likert model. The results showed 1 showed that isolated students in social skills - 20 Cilandak South Jakarta seen the existence of $1(6.7 \%)$ isolated students have very low social skills while for low-there are 5 categories (33.3\%) students were isolated. Category 4 (26.7\%) were students, high-category 3 (20\%) as well as the very high category 2 (13.3\%). The implications of the results of such research can serve as an analysis of the needs of students for making the program BK in improving social skills the students are isolated.

Keywords: Social Skills, Students are Isolated

\section{A. PENDAHULUAN}

Remaja (adolescence) diartikan sebagai masa perkembangan transisi antara masa anak dan masa dewasa yang mencakup perubahan biologis, kognitif dan sosial-emosional (Santrock, 2003:26). Melihat masa remaja sangat potensial dan dapat berkembang ke arah positif maupun negatif maka intervensi edukatif dalam bentuk pendidikan, bimbingan, maupun pendampingan sangat diperlukan untuk mengarahkan perkembangan potensi remaja tersebut agar berkembang ke arah positif dan produktif.

Masa remaja disebut juga sebagai masa social karena sepanjang masa remaja hubungan sosial semakin tampak jelas dan sangat dominan (Ali dkk, 2008:91). Kesadaran akan kesunyian menyebabkan remaja berusaha mencari kompensasi dengan mencari hubungan dengan orang lain atau berusaha mencari pergaulan. Penghayatan kesadaran akan kesunyian yang mendalam dari remaja merupakan dorongan pergaulan untuk menemukan pernyataan diri akan kemampuan kemandiriannya.

Namun, di sisi lain ada banyak masalah yang dihadapi remaja pada perkembangan masa remajanya. Salah satu permasalahan yang tersulit adalah masalah sosial (Hurlock, 213: 1980). Sehingga siswa membutuhkan keterampilan untuk menyelesaikan permasalahan tersebut. salah satunya adalah siswa harus memiliki keterampilan sosial. 
Keterampilan sosial (social skills) mempunyai kedudukan yang sangat penting dalam kehidupan. Keterampilan social akan memberikan citra kualitas kepribadian seseorang dalam berinteraksi dengan orang lain. Tanpa memiliki keterampilan ini, seseorang tidak akan mulus dalam berinteraksi dengan orang lain, sehinggahidupnya kurang harmonis (Sasongko, 2001:70). Cartledge dan Milburn (1995:8) juga menjelaskan bahwa "Social skills are ones or society member ability in establishing relationship with others and his problem solving ability with which a harmonies society can be achieved". Dengan kata lain, keterampilan social merupakan kemampuan seseorang atau warga masyarakat dalam mengadakan hubungan dengan orang lain dan kemampuan memecahkan masalah sehingga memperoleh adaptasi yang harmonis di masyarakat.

Akan tetapi, fenomena yang terjadi menunjukkan masih ada siswa yang belum mempunyai keterampilan sosial yang baik. Hal tersebut terlihat dari hasil pengamatan guru kelas XI di SMKN 20 Cilandak, yaitu: masih ditemukannya beberapa siswa yang kemampuan sosialisasi atau perilaku sosialnya rendah, hal ini terlihat dari beberapa indikasi yang ditunjukkan siswa, seperti: dalam berteman ingin menang sendiri, inginmenguasai orang lain, sulitdiatur, tidak mau mengalah, memilih-milih teman, penyendiri, cepat marah. Indikasi tersebut membuat siswa menjadi siswa yang tidak disenangi oleh teman-temannya.

Selanjutnya, hasil penelitian Sunarya (2005) menjelaskan bahwa dari hasil pengolahan sosiometri diperoleh gambaran dari 294 orang siswa sebanyak 67 orang $(22,79 \%)$ mendapat status sebagai siswa terisolir dan 35 orang $(11,90 \%)$ termasuk siswa yang popular (sangat disenangi) oleh temen-temannya. Hal tersebut dapat dimaknai bahwa masih banyak siswa yang terisolir, artinya siswa belum memiliki keterampilan sosial yang baik terutama di dalam permasalahan relasi atau hubungan yang selanjutnya akan mempengaruhi kehidupan sosial siswa di masa yang akan datang.

Permasalahan yang ditemui di lapangan perlu diatasi dan menjadi tanggung jawab pendidik (guru) untuk membantu menyelesaikan permasalahan siswa tersebut, sehingga siswa memiliki keterampilan sosial yang baik. Salah satu yang memiliki peranan adalah guru bimbingan dan konseling. Bimbingan dan 
konseling (BK) sebagai salah satu bagian integral dari kegiatan pendidikan di sekolah, mempunyai peranan penting dalam upaya pengembangan kemampuan siswa. Pengembangan kemampuan siswa diberikan dalam bentuk bantuan melalui pelaksanaan layanan $\mathrm{BK}$, seperti layanan orientasi, informasi, bimbingan kelompok, konseling perorangan, dan layanan lainnya. Layanan bimbingan dan konseling yang diberikan oleh guru BK nantinya diharapkan mampu membantu menyelesaikan permasalahan rendahnya keterampilan sosial yang dimiliki siswa.

Berdasarkan penjelasan di atas, maka penulis tertarik untuk melakukan penelitian tentang gambaran keterampilan sosial siswa terisolir serta implikasinya dalam pelayanan bimbingan dan konseling.

\section{B. METODOLOGI PENELITIAN}

Penelitian ini menggunakan metode kuantitatif deskriptif. Populasi penelitian ini adalah siswa SMKN 20 Cilandak, yaitu kelas X, XI dan kelas XII yang berjumlah 672 siswa, dan teknik pengambilan sampel menggunakan teknik purposive sampling. Adapun sampel yang dipilih adalah kelas XI dengan jumlah 204 siswa. Selanjutnya, untuk mengetahui siswa terisolir penulis menggunakan instrumen sosiometri dan dari hasil pengolahan maka didapatkan sampel sebanyak 15 orang siswa yang berada pada kategori terisolir. Selanjutnya, instrumen yang digunakan adalah angket keterampilan sosial yang disusun oleh penulis.

\section{HASIL PENELITIAN DAN PEMBAHASAN}

Berdasarkan hasil pengolahan angket keterampilan sosial maka didapatkan hasil sebagai berikut:

\section{Tabel 1}

Gambaran Keterampilan Sosial Siswa Terisolir

\begin{tabular}{|c|c|c|c|c|}
\hline No & Rentang Skor Ideal & Kategori & F & \% \\
\hline 1 & $137-144$ & Sangat Rendah & 1 & 6,7 \\
\hline 2 & $145-152$ & Rendah & 5 & 33,3 \\
\hline 3 & $153-160$ & Sedang & 4 & 26,7 \\
\hline 4 & $161-168$ & Tinggi & 3 & 20 \\
\hline 5 & $169-176$ & Sangat Tinggi & 2 & 13,3 \\
\hline
\end{tabular}


Gambaran Keterampilan Sosial....(Solihatun dan Maria Oktasari)

\begin{tabular}{|c|c|c|c|c|}
\hline No & Rentang Skor Ideal & Kategori & F & $\%$ \\
\hline \multicolumn{3}{|c|}{ Jumlah } & 15 & 100 \\
\hline
\end{tabular}

Berdasarkan tabel di atas, maka dapat dimaknai bahwa kebanyakan siswa memiliki keterampilan sosial yang berada pada kategori rendah, yaitu 5 orang siswa dengan persentase $33,3 \%$.

Selanjutnya gambaran keterampilan sosial siswa terisolir berdasarkan aspekaspek dijelaskan pada tabel 2 .

Tabel 2

Gambaran Keterampilan Sosial Siswa Terisolir Per Aspek

\begin{tabular}{|c|c|c|c|c|}
\hline No & Aspek & Kategori & $\mathbf{F}$ & $\%$ \\
\hline \multirow[t]{5}{*}{1} & \multirow[t]{5}{*}{ Interpersonal } & Sangat Rendah & 1 & 6,7 \\
\hline & & Rendah & 3 & 20 \\
\hline & & Sedang & 7 & 46,7 \\
\hline & & Tinggi & 3 & 20 \\
\hline & & Sangat Tinggi & 1 & 6,7 \\
\hline \multicolumn{3}{|c|}{ Jumlah } & 15 & 100 \\
\hline \multirow[t]{5}{*}{2} & \multirow[t]{5}{*}{ Perilaku Hubungan Diri Sendiri } & Sangat Rendah & 1 & 6,7 \\
\hline & & Rendah & 0 & 0 \\
\hline & & Sedang & 6 & 40 \\
\hline & & Tinggi & 6 & 40 \\
\hline & & Sangat Tinggi & 2 & 13,3 \\
\hline \multicolumn{3}{|c|}{ Jumlah } & 15 & 100 \\
\hline \multirow[t]{5}{*}{3} & \multirow[t]{5}{*}{ Kesuksesan Akademis } & Sangat Rendah & 2 & 13,3 \\
\hline & & Rendah & 2 & 13,3 \\
\hline & & Sedang & 6 & 40 \\
\hline & & Tinggi & 3 & 20 \\
\hline & & Sangat Tinggi & 2 & 13,3 \\
\hline \multicolumn{3}{|c|}{ Jumlah } & 15 & 100 \\
\hline \multirow[t]{5}{*}{4} & \multirow[t]{5}{*}{ PeerAcceptanec } & Sangat Rendah & 3 & 20 \\
\hline & & Rendah & 4 & 26,7 \\
\hline & & Sedang & 5 & 33,3 \\
\hline & & Tinggi & 2 & 13,3 \\
\hline & & Sangat Tinggi & 1 & 6,7 \\
\hline \multicolumn{3}{|c|}{ Jumlah } & 15 & 100 \\
\hline \multirow[t]{5}{*}{5} & \multirow[t]{5}{*}{ Keterampilan komunikasi } & Sangat Rendah & 1 & 6,7 \\
\hline & & Rendah & 1 & 6,7 \\
\hline & & Sedang & 5 & 33,3 \\
\hline & & Tinggi & 7 & 46,7 \\
\hline & & Sangat Tinggi & 1 & 6,7 \\
\hline \multicolumn{3}{|c|}{ Jumlah } & 15 & 100 \\
\hline
\end{tabular}


Berdasarkan tabel 2 di atas, maka dapat disimpulkan bahwa aspek keterampilan sosial siswa terisolir di SMKN 20 Cilandak Jakarta Selatan yang berada pada kategori rendah adalah aspek peer acceptance, sebanyak 4 orang siswa (26,7\%), kategori sedang adalah aspek interpersonal, sebanyak 7 orang siswa $(46,7)$ dan kategori tinggi adalah aspek keterampilan komunikasi, sebanyak 7 orang siswa $(46,7 \%)$.

Hasil penelitian ini secara keseluruhan disimpulkan bahwa gambaran keterampilan sosial siswa terisolir berada pada kategori rendah dengan aspek terendah adalah peer acceptance. Artinya, keterampilan sosial siswa terisolir terjadi karena penerimaan yang kurang baik dari teman sebayanya. Seperti pendapatnya Elksnin \& Elksnin (dalam Adiyanti,1999:7) peer acceptance merupakan perilaku yang berhubungan dengan penerimaan sebaya.

Selanjutnya, Nurihsandan Agustin (67:2011) menjelaskan bahwa salah satu tugas perkembangan masa remaja yang tersulit adalah yang berhubungan dengan penyesuai sosial. Remaja harus menyesuaikan diri dengan lawan jenis dalam hubungan yang sebelumnya belum pernah ada dan harus menyesuaikan dengan orang dewasa. Adapun hal yang tersulit adalah penyesuaian diri dengan meningkatnya pengaruh kelompok sebaya, perubahan dalam perilaku sosial, pengelompokkan sosial yang baru, nilai-nilai baru dalam seleksi persahabatan, nilai-nilai baru dalam dukungan dan penolakan sosial, dan nilai-nilai baru dalam seleksi pemimpin. Hal ini dapat dimakna bahwa keterampilan sosial siswa dipengaruhi oleh penyesuaian diri siswa terhadap lingkungannya, salah satunya adalah kelompok teman sebaya.

Berdasarkan penjelasan di atas, maka dapat disimpulkan bahwa keterampilan sosia siswa terisolir yang rendah harus mendapatkan perhatian dari pendidik (guru). Salah satunya adalah guru BK. Hasil penelitian ini dapat ditindak lanjuti oleh guru BK SMKN 20 Cilandak Jakarta Selatan sebagai pedoman atau dasar untuk menyusun program bimbingan dan konseling terkait dengan tema keterampilan sosial yang dijabarkan dalam layanan bimbingan dan konseling. Sehingga permasalahan dari hasil penelitian ini dapat teratasi. 


\section{SIMPULAN}

Secara umum, Gambaran keterampilan sosial siswa terisolir di SMKN 20 Cilandak Jakarta Selatan berada pada kategori rendah terutama pada aspek Peer Acceptance. Hasil penelitian tersebut perlu ditindaklanjuti oleh guru bimbingan dan konseling di sekolah sebagai analisis kebutuhan siswa untuk pembuatan program BK dalam meningkatkan keterampilan sosial siswa terisolir.

\section{DAFTAR PUSTAKA}

Adiyanti. M. G. (1999). Skala Keterampilan Sosial. Laporan Penelitian. Yogyakarta: Fakultas Psikologi Universitas Gadjah Mada.

Ali, M. \& Asrori, M. (2008). Psikologi Remaja. Jakarta: Bumi Aksara.

Cartledge. G. \& Milburn, J. F. (1995). Teaching Social Skills to Children \& Youth: Innovative Approaches (3rded.). Massachussetts. Allyn and Bacon.

Hurlock. Elizabeth. (1978). Perkembangan Anak. Jakarta: Erlangga.

Hurlock. E. (1980). Psikologi Perkembangan Anak. Jakarta: Erlangga.

Nurihsan, J. (2007). Strategi Layanan Bimbingan dan Konseling. Bandung: Refika Aditama.

Nurihsan, J. \& Agustin, M.. (2011). Dinamika Perkembangan Anak dan Remaja (Tinjauan Psikologi, Pendidikan, dan Bimbingan). Bandung: Refika Aditama.

Sangsoko, N. R. (2001). Model Pembelajaran Aksi Sosial untuk Pengembangan Nilai-Nilai dan Keterampilan Sosial. Disertasi. Program Studi Pendidikan Umum. PPS UPI (tidak diperdagangkan).

Santrock, J.W. (2003). Adolescence Perkembangan Remaja (Edisi Keenam). Jakarta: Erlangga.

Sunarya, Y. (2005). Beberapa Karakteristik Siswa Terisolir (Jurnal Psikologi Pendidikan dan Bimbingan Vol. 1-3.

Yusuf, S. (2009). Program Bimbingan \& Konseling di Sekolah. Bandung: Rizqi Press. 